\title{
Comparative Biology of Fruit Fly, Bactrocera dorsalis (Hendel) on Mango Genotypes
}

\author{
K.S. Ashoka ${ }^{1^{*}}$ and Javaregowda ${ }^{2}$ \\ ${ }^{1}$ Department of Agricultural Entomology, College of Agriculture, Dharwad-580005, India \\ ${ }^{2}$ Department of Forest Biology and Tree Improvement, College of Forestry, \\ Sirsi-581401, India \\ *Corresponding author
}

\section{Keywords}

Comparative biology, Bactrocera dorsalis (Handel), Maggot period, Fecundity, Adult longevity, Genotype, Fecundity

Article Info

Accepted:

26 October 2019

Available Online:

10 November 2019

\section{A B S T R A C T}

Investigation was undertaken at Department of Entomology, College of Agriculture, Dharwad (Karnataka) during 2018-19 to understand the biology of Bactrocera dorsalis (Hendel) on different mango genotypes under laboratory condition. The data on comparative biology of $B$. dorsalis on different genotypes inferred that, the minimum incubation period of 1.5 days was noticed on Alphonso, whereas, it was maximum on Dasheri (3.5days). The minimum maggot period of 7.8 days was noticed on Benishan, whereas, it was maximum on Dasheri (11.3days). The minimum pupal period was recorded on Benishan (10.3 days), while it was maximum of 12.6 days on Dasheri. Among the eight genotypes the adult male longevity was recorded on Benishan and female on Alphonso i.e. (20.6 and 23.9 days) Minimum male and female longevity was on Dasheri (18.3 and 20.4 days). The total development period was significantly highest on Dasheri (27.5 days) and it was found to be minimum on Benishan (19.8 days). The maximum mean fecundity was 189.5 eggs per female on Benishan whereas, minimum with 132.7 eggs per female on Dasheri genotype.

\section{Introduction}

The oriental fruit fly Bactrocera dorsalis (Hendel), first reported in Taiwan Island, is one of the most destructive pests of fruits and vegetables around the world, causing huge economic losses (Wei et al., 2017) and is a serious pest on a wide range of fruit crops in the Indian subcontinent. It is endemic to Southeast Asia, but has also been introduced to various region of the world and became threats to the wide range of cultivated and wild fruits (Drew and Raghu, 2002). Bactrocera dorsalisis reported to cause 100.0, 87.0, 78.0 and $61.0 \%$ fruit damage in rainy season on guava, mango, peach and pear respectively (Sharma et al., 2011). Whereas Singh (2010) reported significant losses in Kinnow due to fruit flies. Mango (Mangifera indica L.) belongs to family Anacardiaceae is one among the important fruit crops grown in the world. It is cultivated in most of the 
tropical and sub-tropical countries of the world for consumption purpose. Being a fruit crop, mango fits well into most of the cropping systems. It is grown as sole crop, border crop, intercrop and in agro-forestry combinations.

The mango fruit as utilized at all stages of its development both in its immature and mature stage. The damage caused on mango by oriental fruit flies resulted from oviposition in fruit, feeding by the maggots and decaying of tissue by invading secondary microorganisms that leads to fruit drop.

Evaluation of the effectiveness and efficacy of control technology require the presence of the appropriate stage, quantity and quality of insect. Even though this pest feed on various crops, the differences in morphological and chemical substance between host fruits may likely interfere in the biology and behaviour of pest. Therefore, the present investigation was carried out to study the comparative biology of $B$. dorsalis (Hendel) on different mango genotypes under laboratory condition.

\section{Materials and Methods}

\section{Mass rearing of Bactrocera dorsalis (Hendel)}

The infested fruits of mango were initially collected from the mango orchard at the KVK farm of College of Agriculture, Dharwad (Karnataka). Culture was maintained under laboratory conditions on fresh mango. Fresh food was provided, during experimental period. Proper hygienic conditions were maintained. Full grown maggots were allowed to pupate in the glass vails with providing soil. Pupae were separated and kept in a separate glass vails. Emerging flies were used to build up subsequent culture. Adults were fed on mixture of milk powder, yeast and honey solution. Fresh mango was placed in the cage to provide for oviposition. Eggs obtained from these flies were further used for different aspects of the study.

\section{Experimental details}

A statistically designed lab experiment using Completely Randomized Design (CRD) having three replications and eight treatments (Each mango genotypes act as treatments) was laid out to study comparative biology of $B$. dorsalis on different mango genotypes in the Entomology laboratory, College of Agriculture, Dharwad (Table 1).

The experiment was started with eggs, (10-12 hr old) obtained from the nucleus culture. The eggs were transferred in individual petri plate containing fresh pulp of Alphonso, Totapuri, Pairi, Neelum, Dasheri, Benishan, Mallika and Rajgira. Fresh pulp of all genotypes was changed in the interval of 2 days. Each petri plate was examined and recorded observation on incubation period, maggot period, pupal period, adult longevity, fecundity, and total developmental period.

\section{Results and Discussion}

\section{Incubation period}

The incubation period of the eggs of $B$. dorsalis on mango fruit under laboratory conditions. Data indicated that significantly maximum incubation period was recorded on Dasheri (3.5 days) followed by Neelum (3.0 days) and Rajgira, Pairi and Mallika (2.5 days). The mean incubation period was significantly lowest on Alphonso (1.5 days) followed by Benishan fruits (1.6 days) than all other mango genotypes.

Kalia, (1992) reported impact of host varieties on egg period was $3.25,3.00,2.25$ and 2.00 days, respectively on Dashehari, Amrapali, Mallika and Bangalora (Table 2). 


\section{Maggot period}

The data indicated that the mean maggot period of $B$. dorsalis was significantly maximum on Dasheri (11.3 days) followed by Neelum (10.6 days) and Rajgira (10.2 days) which were at par. Further, Rajgira was at par with Pairi (9.8 days), Mallika (9.0 days) and Totapuri (8.7 days) which also were further at par with Alphonso (8.0 days). The mean maggot period was significantly the lowest on Benishan fruits (7.8 days) than all other mango genotypes tested (Table 2). Kalia, (1992) reported that studies on varietal differences revealed that the maggot period of D. dorsalis was $6.50,6.00,6.00$ and 7.75 days, respectively on variety Dashehari, Amrapali, Mallika and Bangalora. Kalia and Srivastava (1992) also reported that the maggot period was $9.25,9.00,8.50$ and 6.0 days on fruits of four, three, two and one week before maturity of Amrapali variety. However, it was 9.50, 9.0, 8.25 and 6.0 days on variety Mallika.

\section{Pupal period}

Pupal period on different mango genotypes indicated that the mean pupal period of $B$. dorsalis was maximum on Dasheri (12.6 days) followed by Neelum (12.3 days) which was at par with each other. While, remaining genotypes to follow were Rajgira (11.5 days), Pairi (11.4 days), Mallika (10.8 days), Totapuri (10.9 days), Alphonso (10.5 days) and Benishan (10.3 days). The present studycan be comparable with the results of Kalia, (1992) when D. dorsalis was reared on different varieties of mango, the shortest period was noted on Mallika (7.5 days) followed by Amrapali (8.0 days), Bangalora (8.75 days) and Dashehari (9.0 days). Kalia and Srivastava (1992) reported the pupal period as 8 to 10.50 days on Amrapali and 7.50 to 10.75 days on Malika. Jiji et al., (2006) also reported that pupal period of $B$. dorsalis in the was 10.50 and12.75 days onvariety Neelumand Bangalora respectively (Table 2).

\section{Total developmental period}

The total developmental period from hatching of maggot to emergence of adults from pupa was significantly longer on Dasheri (27.5 days) followed by Neelum (26.0 days). Remaining mango genotypes to follow were Rajgira (24.2 days), Pairi (23.8 days), Mallika (22.3 days), Totapuri (21.7 days) and Alphonso (20.0 days). However, it was found to be shorter on Benishan (19.8 days) (Table $2)$. These results indicated that, the unusual nutrients quality of Dasheri and Neelum for $B$. dorsalis might require prolong feeding relative to other mango genotype such as Benishan and Alphonso. The present studies were confined with the life cycle of $B$. dorsalis took lesser duration on mango variety Mallika (15.75 days) followed by Amrapali (17.00 days), Bangalora (18.50 days) and Dashehari (18.75 days) (Kalia, 1992).

\section{Adult longevity}

The adult longevity of male obtained from maggot reared on different mango genotypes varied from 18.3 to 24.0 days. Maximum male adult longevity (20.6 days) was observed on Benishan followed by the Alphonso (20.1 days) Pairi and Rajgira (18.8 days each) both were at par with each other. Minimum male adult longevity was recorded on Dasheri and Neelum (18.3 days) and maximum female adult longevity (23.9 days) was observed on Alphonso followed by Benishan and Mallika (23.4 and 22.1 days). Totapuri and Rajgira recorded 22.0 days and both were at par with each other. Minimum female adult longevity was recorded on Dasheri and Neelum (20.4 and 20.7 days). Jiji et al., (2006) reported adult longevity of $B$. dorsalis in the variety Neelum and Bangalora was 16.50 and 20.30 days respectively (Table 2 ). 
Table.1 Different mango genotypes used for the study

\begin{tabular}{|l|l|}
\hline TREATMENT & GENOTYPES \\
\hline T1 & Alphonso \\
\hline T2 & Totapuri \\
\hline T3 & Pairi \\
\hline T4 & Neelum \\
\hline T5 & Dasheri \\
\hline T6 & Mallika \\
\hline T7 & Benishan \\
\hline T8 & Rajgira \\
\hline
\end{tabular}

Table.2 Duration of different developmental stages of Bactrocera dorsalis on different mango genotypes reared under laboratory during June to July, 2018

\begin{tabular}{|c|c|c|c|c|c|c|c|}
\hline \multirow[t]{2}{*}{$\begin{array}{c}\text { Mango } \\
\text { genotypes }\end{array}$} & \multirow[t]{2}{*}{ Fecundity** } & \multirow[t]{2}{*}{$\begin{array}{c}\text { Incubation } \\
\text { period* }\end{array}$} & \multirow[t]{2}{*}{$\begin{array}{l}\text { Maggot } \\
\text { period* }\end{array}$} & \multirow[t]{2}{*}{$\begin{array}{l}\text { Pupal } \\
\text { period* }\end{array}$} & \multirow{2}{*}{$\begin{array}{c}\text { Total } \\
\text { developmental } \\
\text { period* }\end{array}$} & \multicolumn{2}{|c|}{$\begin{array}{l}\text { Adult longevity in } \\
\text { days }\end{array}$} \\
\hline & & & & & & Male & Female \\
\hline Alphonso & $\begin{array}{l}187.43 \\
(13.71)^{\mathrm{e}}\end{array}$ & $\begin{array}{c}1.5 \\
(1.41)^{\mathrm{e}}\end{array}$ & $\begin{array}{c}8.0 \\
(2.92)^{\mathrm{ef}}\end{array}$ & $\begin{array}{c}10.5 \\
(3.32)^{\mathrm{e}}\end{array}$ & $\begin{array}{c}20.0 \\
(4.53)^{\mathrm{e}}\end{array}$ & $\begin{array}{c}20.1 \\
(4.54)^{\mathrm{c}}\end{array}$ & $\begin{array}{c}23.9 \\
(4.94)^{\mathrm{b}}\end{array}$ \\
\hline Totapuri & $\begin{array}{l}167.93 \\
(12.98)^{\mathrm{d}}\end{array}$ & $\begin{array}{c}2.1 \\
(1.61)^{\mathrm{d}}\end{array}$ & $\begin{array}{c}8.70 \\
(3.03)^{\mathrm{de}}\end{array}$ & $\begin{array}{c}10.9 \\
(3.38)^{\mathrm{bc}}\end{array}$ & $\begin{array}{c}21.7 \\
(4.71)^{\mathrm{de}}\end{array}$ & $\begin{array}{c}18.5 \\
(4.36)^{\mathrm{ab}}\end{array}$ & $\begin{array}{c}22.0 \\
(4.74)^{\mathrm{ab}}\end{array}$ \\
\hline Pairi & $\begin{array}{l}152.83 \\
(12.38)^{\mathrm{c}}\end{array}$ & $\begin{array}{c}2.5 \\
(1.73)^{\mathrm{c}}\end{array}$ & $\begin{array}{c}9.80 \\
(3.21)^{\mathrm{bc}}\end{array}$ & $\begin{array}{c}11.4 \\
(3.45)^{\mathrm{abc}}\end{array}$ & $\begin{array}{c}23.8 \\
(4.93)^{\mathrm{c}}\end{array}$ & $\begin{array}{c}18.8 \\
(4.39)^{\mathrm{b}}\end{array}$ & $\begin{array}{c}21.8 \\
(4.72)^{\mathrm{ab}}\end{array}$ \\
\hline Neelum & $\begin{array}{l}142.63 \\
(11.96)^{b}\end{array}$ & $\begin{array}{c}3.0 \\
(1.87)^{\mathrm{b}}\end{array}$ & $\begin{array}{c}10.6 \\
(3.33)^{a b}\end{array}$ & $\begin{array}{c}12.3 \\
(3.58)^{\mathrm{ab}}\end{array}$ & $\begin{array}{c}26.0 \\
(5.15)^{\mathrm{ab}}\end{array}$ & $\begin{array}{c}18.3 \\
(4.34)^{\mathrm{a}}\end{array}$ & $\begin{array}{c}20.7 \\
(4.60)^{\mathrm{a}}\end{array}$ \\
\hline Dasheri & $\begin{array}{l}132.73 \\
(11.54)^{\mathrm{a}}\end{array}$ & $\begin{array}{c}3.5 \\
(2.00)^{\mathrm{a}}\end{array}$ & $\begin{array}{c}11.3 \\
(3.44)^{\mathrm{a}}\end{array}$ & $\begin{array}{c}12.6 \\
(3.62)^{\mathrm{a}}\end{array}$ & $\begin{array}{c}27.5 \\
(5.29)^{\mathrm{a}}\end{array}$ & $\begin{array}{c}18.3 \\
(4.34)^{\mathrm{a}}\end{array}$ & $\begin{array}{c}20.4 \\
(4.57)^{\mathrm{a}}\end{array}$ \\
\hline Mallika & $\begin{array}{c}166.36 \\
(12.92)^{d}\end{array}$ & $\begin{array}{c}2.5 \\
(1.73)^{\mathrm{c}}\end{array}$ & $\begin{array}{c}9.0 \\
(3.08)^{\mathrm{cd}}\end{array}$ & $\begin{array}{c}10.8 \\
(3.36)^{\mathrm{bc}}\end{array}$ & $\begin{array}{c}22.3 \\
(4.77)^{\mathrm{cd}}\end{array}$ & $\begin{array}{c}18.7 \\
(4.38)^{b}\end{array}$ & $\begin{array}{c}22.1 \\
(4.75)^{\mathrm{ab}}\end{array}$ \\
\hline Benishan & $\begin{array}{l}189.53 \\
(13.79)^{\mathrm{e}}\end{array}$ & $\begin{array}{c}1.6 \\
(1.45)^{\mathrm{e}}\end{array}$ & $\begin{array}{c}7.80 \\
(2.88)^{\mathrm{f}}\end{array}$ & $\begin{array}{c}10.3 \\
(3.29)^{\mathrm{e}}\end{array}$ & $\begin{array}{c}19.8 \\
(4.51)^{\mathrm{e}}\end{array}$ & $\begin{array}{c}20.6 \\
(4.59)^{d}\end{array}$ & $\begin{array}{c}23.4 \\
(4.89)^{\mathrm{b}}\end{array}$ \\
\hline Rajgira & $\begin{array}{c}146.03 \\
(12.10)^{\mathrm{b}}\end{array}$ & $\begin{array}{c}2.5 \\
(1.73)^{\mathrm{c}}\end{array}$ & $\begin{array}{c}10.2 \\
(3.27)^{\mathrm{b}}\end{array}$ & $\begin{array}{c}11.5 \\
(3.46)^{\mathrm{abc}}\end{array}$ & $\begin{array}{c}24.2 \\
(4.97)^{\mathrm{bc}}\end{array}$ & $\begin{array}{c}18.8 \\
(4.39)^{\mathrm{b}}\end{array}$ & $\begin{array}{c}22.0 \\
(4.74)^{\mathrm{ab}}\end{array}$ \\
\hline S. Em \pm & 1.38 & 0.19 & 0.19 & 0.30 & 0.32 & 0.06 & 0.36 \\
\hline C. D. at $1 \%$ & 3.80 & 0.79 & 0.79 & 1.25 & 1.32 & 0.25 & 1.47 \\
\hline
\end{tabular}

\footnotetext{
*Days ** Numbers
} 


\section{Fecundity}

The fecundity of $B$. dorsalis varied in the different mango genotypes. Highest fecundity was recorded on Benishan and Alphonso with 189.5 eggs and 187.4 eggs which were significantly more than other genotypes. This was followed by Totapuri (167.9 eggs) which were at par with each other. Mallika recorded 166.3 eggs. Further, Pairi (152.8 eggs) and Rajgira (146.0 eggs) were found at par with each other. Rajgira was at par with Neelum (142.6 eggs). Significantly the lowest fecundity was observed on Dasheri (132.7 eggs).Narayanan and Batra (1960) recorded on an average 50 eggs of $D$. dorsalis, but under favourable conditions they observed 150-200 eggs per female in a period of one month (Table 2).

In conclusion, biology of $B$. dorsalis (Hendel) is important to know the susceptible/resistant mango genotypes based on the rate of fecundity on different mango genotypes that support to make efficient strategies to control this economic pest. Based on the resistant/susceptible category, resistant mango genotypes can be used in the breeding programme which helps to propagate for planting of resistant genotypes in the field.

\section{References}

Anonymous, 2017, Horticulture statistics at a glance, Horticulture Statistics Division (HSD) Government of India (GOI), New Delhi. pp. 302-303.

David, K. J. and Ramani, S., 2011, An illustrated key to fruit flies (Diptera: Tephritidae) from Peninsular India and the Andaman and Nicobar Islands. Zootaxa, 3021: 1-31.

Drew, R. A. I. and Raghu, S., 2002, The fruit fly fauna (Diptera: Tephritidae: Dacinae) of the rain forest habitat of the Western Ghats, India. The Raffles Bull. Zool., 50(2): 327- 352.

Jiji, T., Napolean, A., Stonehouse, J.andVerghese, A., 2003, Efficient food baits for trapping fruit flies. Ins. Envir., 9(3): 143-144.

Kalia, V. (1992). Bionomics of fruit fly, D. dorsalis on some cultivars of mango and guava. Bull. Ent., 33 (1-2): 79-87.

Kalia, V. and Srivastava, M. L. (1992). Ovipositional behaviour and development of the oriental fruit fly, Dacus (Strumeta) dorsalis on development stages of mango fruit. Bull. Ent., 33 (1-2): 88-93.

Narayanan, E. S. and Batra, H. N. (1960). Fruit flies and their control. Indian Council of Agricultural Research, New Delhi, pp. 20-24.

Singh, S. K., 2010, Biology of Bactrocera (Zeugodacus) tau (Walker) (Diptera: Tephritidae). Entomol. Res., 40: 259263.

Sharma, D. R., 2011, Comparison of the trapping efficacy of different types of methyl eugenol based traps against fruit flies, Bactrocera spp. infesting Kinnow mandarin in the Indian Punjab. J. Insect Sci., 24: 109-114.

\section{How to cite this article:}

Ashoka, K.S. and Javaregowda. 2019. Comparative Biology of Fruit Fly, Bactrocera dorsalis (Hendel) on Mango Genotypes. Int.J.Curr.Microbiol.App.Sci. 8(11): 2482-2486. doi: https://doi.org/10.20546/ijcmas.2019.811.286 